\title{
EXPLORING THE IMPACT OF INFLATION AND EXTERNAL DEBT ON ECONOMIC GROWTH IN MOROCCO: AN EMPIRICAL INVESTIGATION WITH AN ARDL APPROACH
}

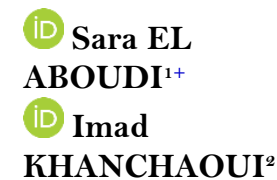

Article History

Received: 25 June 2021

Revised: 22 September 2021

Accepted: 18 October 2021

Published: 15 November 2021

\section{Keywords \\ Inflation \\ External debt \\ Economic growth \\ ARDL \\ Short and long term \\ Bounds test.}

JEL Classification:

C50; E31; H63; O40.

\author{
${ }^{1,2}$ Organizational Management Sciences Lab National School of Business \\ and Management (ENCG) Ibn Tofail University, Kénitra, Morocco. \\ 'Email: Sara.elaboudi@uit.ac.ma Tel: +212670493501 \\ ${ }^{2}$ Email:Imad.khanchaoui@uit.ac.ma Tel:+212641454852
}

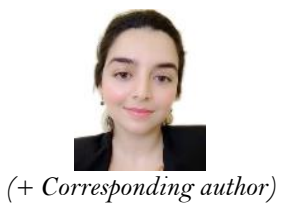

ABSTRACT
This article seeks to empirically assess the effect of inflation and external debt on economic growth in Morocco. The estimates cover the period from 1985 to 2019. The results from the ARDL model show that external debt negatively influences the country's growth in the short and long terms. Due to its direct effect, inflation slows down economic activity and leads to lower GDP growth. The econometric estimate indicates that the low level of inflation leads to difficulties in repaying debt and, consequently, reduced economic growth. Low inflation also hurts economic competitiveness among small and medium enterprises (SMEs). Although the inflation rate is lower than the interest rates, it reduces the profit margins of companies and leads to lower investment. The negative effect on economic competitiveness leads to decreased sectoral added value, reducing future economic growth rates. Based on the results, two main measures are proposed to mitigate the negative effect of inflation and debt on economic growth. First, we must develop better institutional and governance quality. The latter allows debt funds to be well spent on non-rent-producing sectors capable of reviving the Moroccan economy. Second, we have to look for good inflation, in other words, inflation that stimulates economic activity without creating economic distortions.

Contribution/Originality: This study is one of the few studies that has examined the effects of inflation and foreign debt on the economic growth of Morocco. Compared to previous studies that addressed the determinants of economic growth, our study also addresses the interaction effects of inflation and debt.

\section{INTRODUCTION}

Governments have primary economic and social goals that they want to achieve. These goals require financial resources to stimulate economic activity and, in particular, to support economic growth. These financial resources represent fiscal space, particularly tax revenues, borrowing, public aid, the efficiency of public spending, and debt. Concerning public debt, this is characterized by complex conditions. Although this form of external financing is a crucial source of financing for developing countries, the issue lies in the management of public debt. This intelligence has manifested itself in everything from rational debt spending to technical assistance and good governance.

In times of economic and health crisis, the link between external debt and economic growth continues to drive the debate on debt's effectiveness, terms, and conditions. The debate was also motivated by the interest of economic 
decision-makers and the research agenda among academics. Diamond (1999) argues that debt has beneficial effects on the financing of the economy. It reduces the over-accumulation of capital because it is certified by liquidity restrictions affecting the financial results of specific economic agents (Woodford, 1990). Barro (1979) adds that debt reduces taxes and stimulates investment and economic growth. Other studies, such as that by Saint-Paul (1993), revealed that external debt develops the financial capacity of an economy and contributes to the financing of the public offer. However, the results of these articles are mixed and remain linked to the research methodology, the study period, and the various econometric specifications estimated.

Like many developing countries, Morocco's public debt is still on the rise. Admittedly, the outstanding Moroccan debt recorded an increase in 2016 it was 533.9 billion dirhams and rose to 723.8 billion dirhams in 2019. Regarding external debt, it follows the same logic. Morocco's outstanding debt rose from $\$ 44.63$ billion in 2016 to $\$ 62.45$ in 2019. The significant increase in debt makes it a structural fiscal problem, and the insufficiency of public revenue in the face of the upward trend in public spending generates a structural public deficit ${ }^{1}$.

Consequently, the instability of public finances leads to a strong dependence of the State budget on external financing. Thus, the Moroccan economy is characterized by a volatile economic growth rate, which is strongly correlated with climatic hazards. As a result, economic recovery is often associated with the size of the debt and its transmission channels.

In addition, Morocco's financial difficulties are worsening. The budget balance sheet is widely exploited, interest rates on the country's debt are high, the need for financing is increasing, and the public deficit is also increasing. These non-exhaustive financial difficulties tell us about the significant macroeconomic imbalances in the Moroccan economy. In addition, there is the effect of the inflation rate, which is at a low level and is a research element in this study. The interaction of inflation with debt allows us to draw meaningful conclusions about economic growth.

In light of the above, and given the importance of debt as an instrument of fiscal policy, two major questions arise: To what extent do inflation and external debt affect Moroccan economic growth? What role does inflation play regarding economic growth?

The main objective of this study is to assess the effects of inflation and external debt on Morocco's economic growth. Our work is based on the following specific research hypotheses:

H1: External debt leads to increased economic growth.

H2: High inflation harms the variation of real GDP.

H3: Low inflation leads to debt repayment difficulties and reduced economic growth.

Our study is divided into four parts. The first part deals with the literature review; the second part is devoted to the presentation of the main stylized Moroccan facts; the methodology and data sources are presented in the third part; and the last part of the study comprises the results and discussions.

\section{THE LITERATURE REVIEW}

The first work on public debt dates back to studies by Corden (1988) and Krugman \& Paul (1988). At the outset, the authors found that outstanding external debt hurts economic growth. This negative relationship of overindebtedness is explained by the early repayment of external debt, which remains well below its contractual value. The authors also added that if a country's debt threshold exceeds the future repayment threshold, the expected debt service will be an increasing function of its level of production.

Cohen (1993) shows that a Laffer curve represents the link between outstanding debt and investment. When the outstanding debt exceeds the optimal threshold, the expected debt repayment decreases due to the adverse effects of debt. In the same vein, Agénor \& Peter (1996) show that over-indebtedness increases uncertainty and

\footnotetext{
${ }^{1}$ A structural deficit exists when there is a persistent tendency for revenues to fall short of government expenditures.
} 
reduces physical capital, and therefore reduces economic growth. Thus, an increase in outstanding debt does not allow the financing of obligations (for debt service) through tax revenue.

Serven \& Luis (1997) argue that investments are likely to channel a better return on public debt. The authors indicate that the adjustment mechanism is rapid, profitable, and low risk if the debt is oriented towards productive investments. Higher returns accompany the rapid adjustment of debt on capital and causes a revival of economic growth. On the other hand, the authors show that if the debt is intended for consumption, the pace of economic growth will be meager, especially in a devalued economy.

In another study, Diamond (1999) suggests that increasing public debt raises interest rates, and rising interest rates lead to lower investment and consumption. This causes difficulties for the financial capacity of economic actors.

Chowdhury (2001) examined the relationship between external debt and growth in developing countries using a regression analysis. The author suggests a negative relationship between debt and economic growth, especially in heavily indebted countries.

Based on a vector error correction model (VECM) using data from 1956 to 1996, Karagöl \& Erdal (2002) show that debt servicing harms Turkey's growth in the short and long terms. The study also adds that there is a one-way causal link between debt service and GDP growth. In 2008, Hameed et al. affirmed the same observation in Pakistan from 1970 to 2003. Similarly, during the period between 1970 and 1995, Were (2001) found that the stock of accumulated debt reduced the sustainability of Kenya's growth.

Using a sample of low-income countries over the period from 1970 to 1999, Clements, Bhattacharya, \& Nguyen (2003) assessed the effect of debt on economic growth. The authors argued that a high level of debt is an obstacle to stimulating economic growth. They also indicated that the relationship between debt and economic growth is affected by the efficient use of resources. When resources exceed 50\% of GDP, debt has adverse effects on the change in real GDP.

Pattillo, Hélène, \& Luca (2004) studied the role of physical capital in the relationship between public debt and economic growth. They studied a panel of 61 developing countries in sub-Saharan Africa, Asia, Latin America, and the Middle East from 1969 to 1998. The results show that the effect of debt is statistically insignificant. However, if it is moderated by physical capital, the effect of debt becomes positive and high. The authors concluded that physical capital is an efficient transmission channel between debt and economic growth.

Sen, Kasibhatla, \& Stewart (2007) conducted a study on Latin American countries between 1970 and 2000 and Asian countries between 1982 and 2002. Using the generalized method of moments (GMM), the authors revealed that external debt is detrimental to economic growth. This impact is significant in Latin American countries.

Ferreira (2009) carried out a causality study in Granger's sense for twenty OECD countries from 1988 to 2001. The study indicated that the increase in debt has hampered economic growth, and the author concluded that causality is bidirectional. In other words, the growth of real GDP influences the evolution of public debt.

In a panel data study of 20 countries with high external debt, Hwang, Chung, \& Wang (2010) assessed the relationship between financial development, external debt, and economic growth from 1982 to 2004 . The researchers noted that high debt reduces economic growth, arguing that excessive debt weakens the rate of GDP growth.

Westphal \& Rother (2012) assessed the impact of high public debt on economic growth in twelve euro area countries between 1970 and 2012, and they observed a non-linear effect of debt on economic growth. Thus, the transmission channels explain the non-linear effect, namely private savings, public investment, and total factor productivity.

In a panel study of six WAEMU countries covering the period from 1985 to 2018, Jerome (2013) showed that external debt stimulates economic growth. The author also concluded that, beyond a threshold of $51 \%$ of the GDP, external debt slowed down the economic growth of the WAEMU countries. 
Ben (2014) conducted a study covering the period between 2006 and 2013 based on the generalized method of moments for a sample of 35 euro area countries and argued that interest on public debt hurts real GDP growth.

Using the PTR model on a panel of eight countries covering the period from 1972 to 2012, Guissé (2016) found that below a rate of $80 \%$, external debt has a positive impact on economic growth. The author also added that external debt harms growth if the rate exceeds $80 \%$ of GDP.

Oumansour \& Chkiriba (2019) studied the effect of external debt on economic growth in Morocco. They used the ARDL model as an economic modeling technique covering the period from 1988 to 2016. The results asserted that external debt has a negative and significant influence on economic growth in the short and long terms.

Sani, Said, Ismail, \& Mazlan (2019) studied the institutional quality of the impact of debt on economic growth. They used the GMM on a sample of 46 countries in sub-Saharan Africa over the period from 2000 to 2014. The empirical result indicated that institutional quality had both a direct and indirect impact on economic growth and thus revealed that institutional quality and public debt had a statistically significant impact on the debt-growth relationship. This confirms the hypothesis that the impact of public debt on economic growth is a function of institutional quality. In addition, government efficiency, corruption control and regulatory quality greatly influence the negative impact of public debt on economic growth in sub-Saharan Africa.

Ndoricimpa (2020) examined the threshold effects of public debt on economic growth in Africa. Using the GMM technique to control debt endogeneity, the author found that low debt is neutral for real GDP growth. However, high debt slows down and hurts economic growth, which depletes the state's budgetary resources. This scenario shows that the debt threshold has been estimated at $74.3 \%$ of GDP.

\section{MAIN MOROCCAN STYLIZED FACTS}

First, it is necessary to present the findings in stylized facts before proceeding to an empirical demonstration of the supposed relationship between inflation, external debt, and economic growth.

\subsection{The Evolution of the Economic Growth Rate in Morocco}

Since Morocco's independence, economic growth rates have fluctuated considerably. Given that the Moroccan economy is strongly linked to fluctuations in the agricultural sector, these fluctuations were very significant during the period from 1985 to 1999 . The economic growth rate fluctuated at an average of $4.1 \%$ during this period.

Figure 1 illustrates the evolution of the economic growth rate in Morocco.

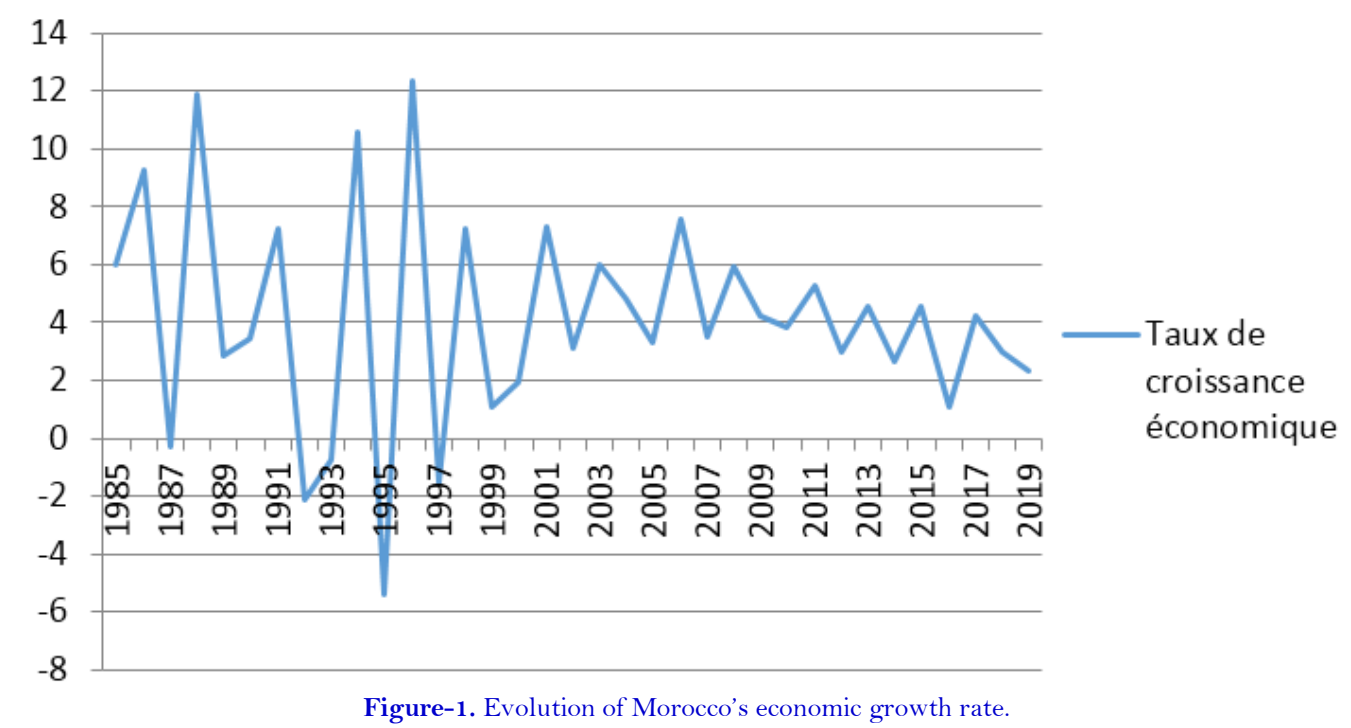


Over the years, the volatility of the economic growth rate has reduced due to the progress made in economic recovery. Since 2000, the Moroccan government has carried out several economic and social reforms, which have boosted the Moroccan economy. This economic revival is linked to the emergence of specific value-added sectors and the efforts made by the State in terms of independence from climatic hazards.

Morocco's economic growth is mainly driven by agricultural GDP. As a result, the efforts undertaken by the government, particularly in terms of economic recovery, remain limited. These efforts were aimed at unproductive and sometimes rentier sectors. They were also adding the weak profile of Moroccan economic growth and as a result, fiscal policy was ineffective.

\subsection{Examination of the Evolution of the External Debt in Morocco}

External debt refers to the relationship between local debtors and foreign lenders. Therefore, the study of the evolution of this macroeconomic variable remains unquestionable, especially since the Moroccan economy has undergone several structural changes. These changes will also bring about a transformation in the behavior of external financiers.

Figure 2 shows the relationship between economic growth and external debt as a percentage of GDP during the 1985-2019 period.

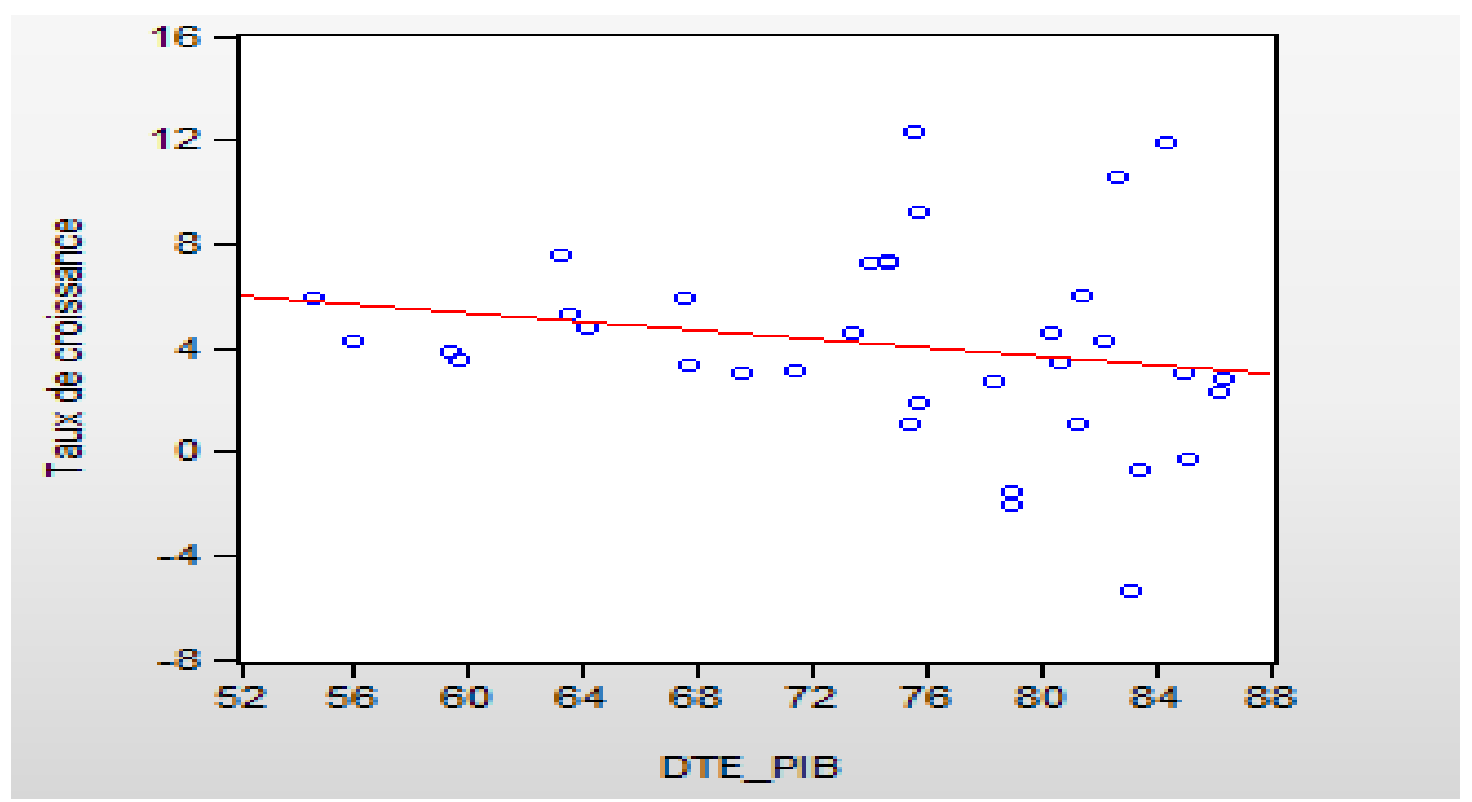

Figure-2. Relationship between economic growth and external debt.

Table 1 shows the evolution of external debt as a percentage of GDP.

Table-1. Change in external debt as a percentage of GDP.

\begin{tabular}{c|c|c|c}
\hline Year & $\mathbf{1 9 8 5 - 1 9 9 0}$ & $\mathbf{1 9 9 0 - 2 0 0 0}$ & $\mathbf{2 0 0 0 - \mathbf { 2 0 1 9 }}$ \\
\hline Debt/GDP & $82.30 \%$ & $78.48 \%$ & $70.67 \%$ \\
\hline
\end{tabular}

During the two decades of the 1980s and 1990s, the debt-to-GDP ratio reached its highest level and an average of $83.1 \%$ of GDP was recorded during this period. In fact, at that time, the state of public finances was fragile and macroeconomic imbalances indicated the deterioration of the Moroccan economy. This situation prompted the public authorities to adopt a structural adjustment program (SAP) as part of the program against external shocks. Conversely, the share of external debt declined until 2007 from $75.64 \%$ in 2000 to $59.60 \%$ in 2007 . This remarkable decline is linked to state intervention in various Moroccan economic sectors. Economic policies have also 
contributed to improving the macroeconomic framework and accelerating the country's economic and social development.

The privatization of public enterprises during the 2000s is an economic policy that has boosted the Moroccan economy, mainly the communication sector. Privatization has had some beneficial effects, notably increased public revenue and a reduction in outstanding debt. Economic growth was also affected by the massive investment in the communication sector.

From 2008, and following the effect of the international economic crisis, the level of external debt had increased again. This increase was mainly due to the rise in commodity prices, the high cost of food and fuel subsidies, and the rise in interest and commission charges following the increase in external debt stock. To this end, the level of debt rose steadily, from $54.60 \%$ of GDP in 2008 to $86.12 \%$ of GDP in 2019.

Consequently, this debt dynamic has had adverse effects on several economic variables. The financial shock of 2008 led to a remarkable fall in foreign exchange in the face of increasing local market needs in terms of consumption and investment. As a result, debt-generating external capital flows contributed only $36 \%$ of external financing needs.

\subsection{Analysis of the Evolution of the Inflation Rate in Morocco}

One of the monetary policy purposes is to ensure the general price level's stability and combat large fluctuations in inflation. Figure 3 below illustrates the evolution of the Moroccan inflation rate during the 19852019 period.

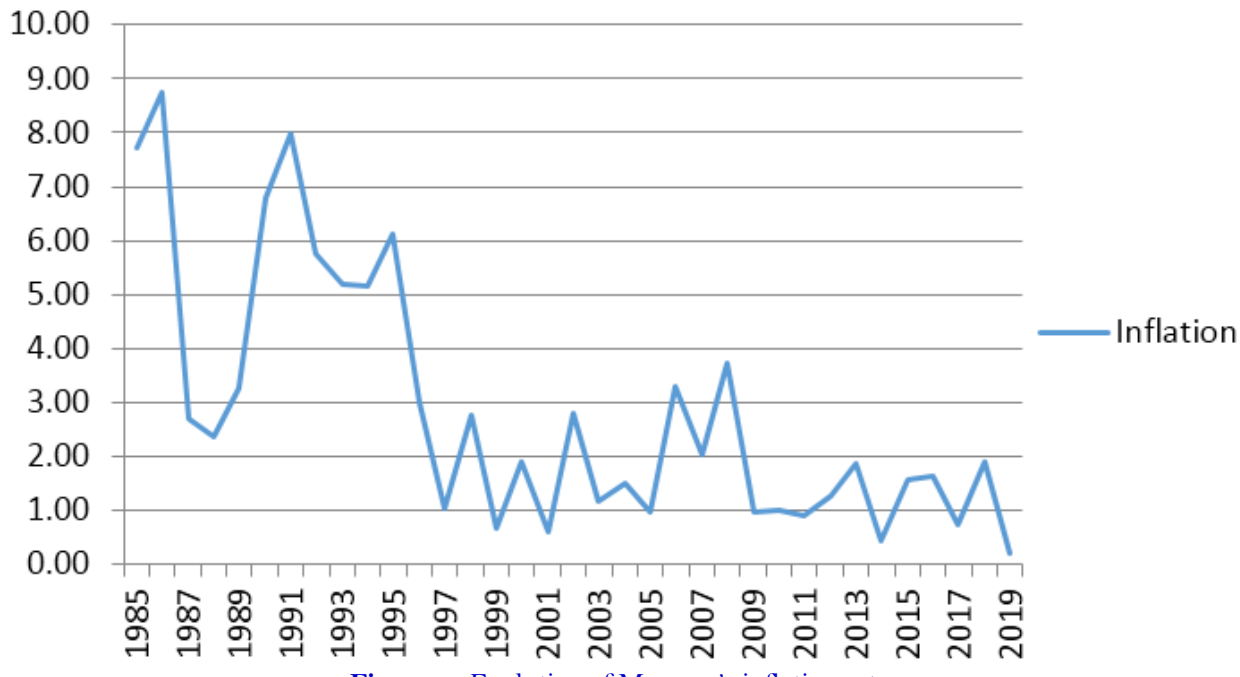

Figure-3. Evolution of Morocco's inflation rate.

The Moroccan economy experienced high inflation in the 1980 s and 1990 s and has been able to control its inflation rate over the last 20 years. Between 1985 and 1990, the inflation rate averaged a high of $7.1 \%$. However, this period was characterized by a lack of macroeconomic rebalancing mechanisms, which prompted the Moroccan government to adopt a structural adjustment program (SAP). Since the 1990s, the inflation rate has declined by two percentage points. These years were a period of significant transition in Morocco through various measures adopted under the structural adjustment program. These have given some results.

Nevertheless, the failure of SAP and the evolution of national and international economic conjectures are the root causes of macroeconomic instability. However, in the 2000s, with the consolidation of the central bank's position and the establishment of institutional reforms, the efforts of the monetary authorities achieved the goal of stabilizing the overall price level. Except for the peak of the international crisis in 2008, the inflation rate fell below $2 \%$. Monetary policy was adjusted macroscopically, and the inflation rate dropped to $0.87 \%$. Therefore, setting the 
inflation target at a controlled rate may seem beneficial in the short-term, but in the long-term, it will slow down economic activity, especially the level of investment by small and medium enterprises (SMEs).

\section{METHODOLOGICAL FRAMEWORK}

The literature review allows us to identify the different channels through which external debt can impact economic growth. The main channel is the inflation rate. This section first specifies the econometric model and the source of the variables used, and then we present the econometric estimation method.

\subsection{Model Specification and Data Source}

This study considered certain variables suggested by economic theory or variables that were tested in other countries, particularly developing countries.

The specification of the model is as follows:

GDPG $=\mathrm{f}($ GFS, SES, Trade, POP, Debt, Infl $)$

We emphasize that the inflation rate is a relevant variable for our econometric study. As mentioned in the study's objective, inflation has an indirect effect on economic growth through its interaction with external debt.

In our econometric modeling, the inflation rate represents a moderating effect between external debt and the change in GDP.

Table 2 presents the expected effect of the explanatory variables suggested by the literature.

Table-2. Description of the variables.

\begin{tabular}{l|l|c}
\hline Variables & Description & Expected Effect \\
\hline Explanatory variables & $(+)$ \\
\hline GFS & Gross fixed capital formation & $(+)$ \\
\hline SES & Secondary school enrollment rate & $(+)$ \\
\hline Trade & The opening rate: (X+M)/GDP & $(+)$ \\
\hline POP & The growth rate of the employed population & $(+)$ \\
\hline Debt & External debt as a percentage of GDP & $(-)$ \\
\hline Infl & The inflation rate & \\
\hline \multicolumn{2}{l}{ The variable to be explained } & \\
\hline GDPG & The growth rate of GDP per capita \\
\hline
\end{tabular}

The data used for the estimates are annual and cover the period from 1985 to 2019 and were obtained from the World Bank database.

\subsection{Estimation Method}

We examined the impact of inflation and external debt on economic growth in Morocco using the ARDL bounds testing approach developed by Pesaran \& Shin (1998) and Pesaran, Shin, \& Smith (2001). This approach offers the possibility of testing long-run relationships using bounds tests on series that are integrated of order (0) and (1) and obtaining better estimates on small samples (Narayan, 2005).

The basic equation of the ARDL bounds testing model is generally written as follows:

$$
Y_{t}=a_{0}+a_{1} Y_{t-1}+\cdots+a_{p} Y_{t-p}+\beta_{0} X_{t}+\beta_{1} X_{t-1}+\beta_{2} X_{t-2}+\cdots+\beta_{q} X_{t-q}+\varepsilon_{t}
$$

From this equation, we note that the dependent variable is explained by the explanatory variable and its lags and the lags of the exogenous variables. Assuming that it has two explanatory variables used in the modeling in addition to the dependent variable, the model is as follows: 


$$
\Delta Y_{\mathrm{t}}=a_{0}+\sum_{\mathrm{i}=1}^{\mathrm{p}} a_{\mathrm{i}} \Delta Y_{\mathrm{t}-\mathrm{i}}+\sum_{\mathrm{i}=0}^{\mathrm{q}} \gamma_{\mathrm{i}} \Delta X_{1 \mathrm{t}-\mathrm{i}}+\sum_{\mathrm{i}=0}^{\mathrm{q}} \delta_{\mathrm{i}} \Delta X_{2 \mathrm{t}-\mathrm{i}}+\theta E C T_{\mathrm{t}-1}+\varepsilon_{\mathrm{t}}
$$

Where:

ECT is the adjustment speed to the long-run equilibrium, and $\theta$ represents the error correction coefficient.

We replace the speed of adjustment to equilibrium by $Y_{t-i}, X_{1 t-i}$ and $X_{2 t-i}$.

The new model becomes:

$$
\Delta Y_{\mathrm{t}}=a_{0}+\sum_{\mathrm{i}=1}^{p} a_{\mathrm{i}} \Delta Y_{\mathrm{t}-\mathrm{i}}+\sum_{\mathrm{i}=0}^{\mathrm{q}} \gamma_{\mathrm{i}} \Delta X_{1 \mathrm{t}-\mathrm{i}}+\sum_{\mathrm{i}=0}^{\mathrm{q}} \delta_{\mathrm{i}} \Delta X_{2 \mathrm{t}-\mathrm{i}}+\theta_{0} Y_{\mathrm{t}-1}+\theta_{1} X_{1 \mathrm{t}-1}+\theta_{2} X_{2 \mathrm{t}-1}+\varepsilon_{\mathrm{t}}
$$

This equation is attributed to an error correction model, as per Pesaran et al. (2001). It allows for joint modeling of short-term dynamics represented by the variables in the first difference, and long-term dynamics represented by the variables in level. ARDL modeling allows us to take the problem of multicollinearity between the explanatory variables into consideration.

By adopting the ARDL bounds testing approach, the model to be estimated is as follows:

$$
\begin{aligned}
\triangle G D P G=a_{0} & +\sum_{i=1}^{p} a_{1 i} G D P G_{t-i}+\sum_{i=0}^{q} a_{2 i} G S F_{t-i}+\sum_{i=0}^{q} a_{3 i} S E S_{t-i}+\sum_{i=0}^{q} a_{4 i} \text { Trade }_{t-i} \\
& +\sum_{i=0}^{q} a_{5 i} P O P_{t-i}+\sum_{i=0}^{q} a_{6 i} D_{e b t_{t-i}}+\sum_{i=0}^{q} a_{7 i} \text { Infl }_{t-i}+\theta_{1} G D P G_{t-1}+\theta_{2} G S F_{t-1} \\
& +\theta_{3} \text { SES }_{t-1}+\theta_{4} \text { Trade }_{t-1}+\theta_{5} P O P_{t-1}+\theta_{6} \text { Debt }_{t-1}+\theta_{7} \text { Infl }_{t-1}+\varepsilon_{t}
\end{aligned}
$$

With:

$\Delta=$ the differentiation operator.

$\mathrm{P}=$ the lag of the endogenous variable.

$\mathrm{q}=$ the maximum lag of the exogenous variables.

$a_{p}=$ the parameters of the long-run relationship.

$\beta_{p}=$ the parameters of the short-run relationship.

\section{RESULTS AND DISCUSSIONS}

The first step of the ARDL modeling consists of testing the stationarity of the study variables. This step allows us to determine the order of integration of the variables, which must be between 0 and 1 . To do this, we use the augmented Dickey-Fuller (ADF) unit root test. Table 3 presents the results of the degree of integration of the variables.

The results in the table above affirm the existence of variables that are integrated of the same order $(\mathrm{I}(1))$, while the inflation rate variable is stationary at level $(\mathrm{I}(0))$. These results suggest the validation of the first condition of the ARDL model. Thus, the cointegration analysis between economic growth and the explanatory variables is an essential condition in the ARDL model. This approach verifies the existence of long-run dynamics in the equation for the variation of GDP. 
Table-3. Results of the ADF unit root test.

\begin{tabular}{c|c|c|c|c|c}
\hline \multirow{2}{*}{ Variables } & \multicolumn{2}{|c|}{ Level } & \multicolumn{2}{c}{ Frist Difference } & Degree of integration \\
\cline { 2 - 6 } & Statistics & P-value & Statistics & P-value & \\
\hline GDPG & -0.91 & 0.3117 & -13.51 & 0.0000 & $\mathrm{I}(1)$ \\
\hline GSF & -2.92 & 0.1672 & -5.61 & 0.0003 & $\mathrm{I}(1)$ \\
\hline SES & -0.86 & 0.9481 & -4.41 & 0.0069 & $\mathrm{I}(1)$ \\
\hline Trade & 0.83 & 0.8875 & -6.92 & 0.0000 & $\mathrm{I}(1)$ \\
\hline PoP & 2.10 & 0.9895 & -5.40 & 0.0276 & $\mathrm{I}(1)$ \\
\hline Debt & -1.79 & 0.3784 & -2.40 & 0.0182 & $\mathrm{I}(1)$ \\
\hline Infl & -2.59 & 0.0112 & - & - & $\mathrm{I}(0)$ \\
\hline
\end{tabular}

To test the existence of cointegration between series, the econometric literature proposes several tests or approaches, including the cointegration test of Pesaran et al. (2001), which has been used as an analytical tool when there is a set of variables with a different order of integration.

The test by Pesaran et al. (2001) is expressed as follows: the hypothesis of the existence of a cointegrating relationship (Ho) is accepted if the calculated Fisher value is greater than the critical upper bound value.

The study of cointegration first requires the determination of the optimal number of lags. We use the Akaike Information Criterion (AIC) to select the optimal ARDL model, the one that provides statistically significant results with the least number of parameters.

Below are the estimation results of the selected optimal ARDL model.

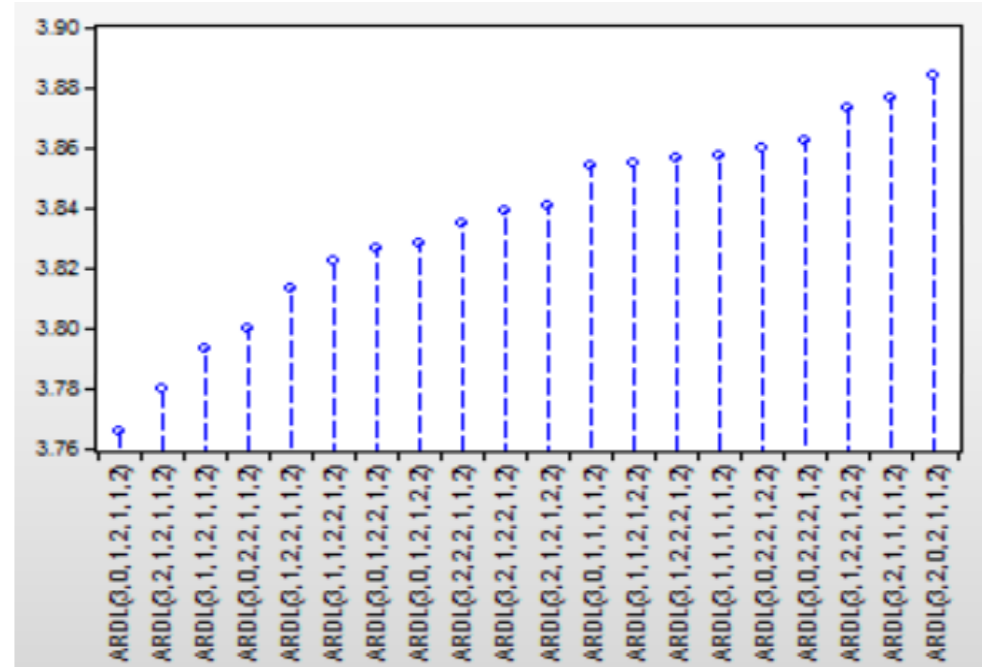

Figure-4. Akaike Information Criterion (AIC) (Source: Authors' elaboration/EViews 9 software).

The following table summarizes the delays of our optimal model:

Table-4. Number of optimal lags.

\begin{tabular}{c|c|c|c|c|c|c|c}
\hline Variables & GDPG & GSF & SES & POP & Trade & Debt & Infl \\
\hline Optimal number of delays & $\mathrm{p}$ & $\mathrm{q} 1$ & $\mathrm{q} 2$ & $\mathrm{q} 3$ & $\mathrm{q} 4$ & $\mathrm{q} 5$ & $\mathrm{q} 6$ \\
\hline & 3 & 0 & 1 & 2 & 1 & 1 & 2 \\
\hline
\end{tabular}

Given the results obtained, the ARDL model $(3,0,1,2,1,1,2)$ is optimal among the 19 others presented. Moreover, the following tests show that there is no autocorrelation of the errors and the heteroscedasticity, as well as the errors, are normal. Therefore, the estimation of the above model is well specified as the p-values associated with the tests are greater than $5 \%$.

Table 5 presents the tests of violation of the stochastic assumptions of the ARDL model. 
Table-5. Tests for violation of the stochastic hypotheses of the ARDL model.

\begin{tabular}{l|l|c|c}
\hline Hypothesis & Test & Statistics & P-value \\
\hline Autocorrelation & Breusch-Godfrey & 5.34 & 0.1203 \\
\hline Heteroscedasticity & Breusch-Pagan-Godfrey & 2.79 & 0.3264 \\
\hline Normality & Jarque-Bera & 2.85 & 0.2393 \\
\hline
\end{tabular}

After estimating the ARDL model, we can perform the Pesaran bounds cointegration test. The computed test statistic, Fisher's F-value, will be compared to the critical values. Table 6 provides the results of the Pesaran cointegration test.

Table-6. Results of the Pesaran cointegration test.

\begin{tabular}{c|c|c}
\hline & \multicolumn{2}{|c}{ Value } \\
\hline F calculated & \multicolumn{2}{|c}{$\mathbf{6 . 9 6}$} \\
\hline $10 \%$ & 2.12 & 3.23 \\
\hline $5 \%$ & 2.45 & 3.61 \\
\hline $2.5 \%$ & 2.75 & 3.99 \\
\hline $1 \%$ & 3.15 & 4.43 \\
\hline
\end{tabular}

The results of the cointegration test confirm the existence of a cointegrating relationship between the series studied (the value of F-stat $=6.96$, which is greater than that of the upper bound (3.61) at the $5 \%$ threshold), which makes it possible to estimate the long-term relationship between economic growth and the explanatory variables.

After detecting the cointegrating relationship between the study variables, we proceed to estimate the parameters of the ARDL econometric model in the short and long runs.

Table 7 presents the estimation of the short-term parameters.

Table-7. Estimation of short-term parameters

\begin{tabular}{c|c|c|c|c}
\hline Variable to be explained: the rate of economic growth & Standard deviation & t-statistics & P-value \\
\hline Explanatory variables & Coefficient & 0.36 & 4.02 & $0.0011^{* * *}$ \\
\hline $\mathrm{D}(\mathrm{GDPG}(-1))$ & 1.45 & 0.16 & 2.82 & $0.0128^{*} *$ \\
\hline $\mathrm{D}(\mathrm{GDPG}(-2))$ & 0.46 & 0.25 & 2.35 & $0.0325^{* *}$ \\
\hline $\mathrm{D}(\mathrm{GSF})$ & 0.61 & 0.32 & 1.90 & $0.0761^{*}$ \\
\hline $\mathrm{D}(\mathrm{SES})$ & 0.61 & 5.02 & -2.94 & $0.0101^{* * *}$ \\
\hline $\mathrm{D}(\mathrm{POP})$ & -14.79 & 5.85 & -1.55 & 0.1400 \\
\hline $\mathrm{D}(\mathrm{POP}(-1))$ & -9.12 & 0.09 & 1.69 & 0.1116 \\
\hline $\mathrm{D}(\mathrm{TRADE})$ & 0.16 & 0.14 & -7.60 & $0.0000^{* * *}$ \\
\hline $\mathrm{D}(\mathrm{DEBT})$ & -1.10 & 0.36 & -4.89 & $0.0002^{* * *}$ \\
\hline $\mathrm{D}(\mathrm{INFL})$ & -1.79 & 0.25 & -2.73 & $0.0152^{* * *}$ \\
\hline $\mathrm{D}(\mathrm{INFL}(-1))$ & -0.69 & 0.46 & -7.63 & $0.0000^{* * *}$ \\
\hline $\mathrm{CointEq}(-1)$ & -0.56 & & & 0 \\
\hline
\end{tabular}

Note: ${ }^{*}, * *$ and ${ }^{*} * *$ indicate significance at the $10 \%, 5 \%$ and $1 \%$ levels, respectively.

Table 8 presents the estimation of the long-term parameters.

Table-8. Estimation of long-term parameters

\begin{tabular}{c|c|c|c|c}
\hline \multicolumn{5}{c}{ Variable to be explained: the rate of economic growth } \\
\hline Explanatory variables & Coefficient & Standard deviation & t-statistics & P-value \\
\hline GSF & 0.17 & 0.07 & 2.36 & $0.0317^{* *}$ \\
\hline SES & 0.01 & 0.04 & 0.38 & 0.7047 \\
\hline POP & -1.04 & 0.14 & -7.32 & $0.0000^{* * *}$ \\
\hline TRADE & 0.11 & 0.03 & 0.15 & $0.0065^{* * *}$ \\
\hline DEBT & -0.20 & 0.02 & -7.75 & $0.0000^{* * *}$ \\
\hline INFL & -1.002 & 0.10 & -9.96 & $0.0000^{* * *}$ \\
\hline C & 85.88 & 10.18 & $0.0000^{* * *}$ \\
\hline
\end{tabular}

Note: $* * *$ and $* * *$ indicate significance at the $10 \%, 5 \%$ and $1 \%$ levels, respectively. 
- $\quad$ Estimated short-term regression :

$$
\begin{gathered}
\widehat{G D P G}_{t}=1,45 G D P G_{t-1}+0,46 G D P G_{t-1}+0,64 G S F_{t}+0,61 S E S_{t}-14,79 P O P_{t}-9,12 P O P_{t-1}+0,16 \text { Trade }_{t-1} \\
-1,10 \text { Debt }_{t-1}-1,79 \text { Infl }_{t}-0,69 \text { Infl }_{t-1}-0,69 \text { Cointeq }_{t-1}
\end{gathered}
$$

- $\quad$ Estimated long-term regression:

$$
\widehat{G D P G}_{t}=85,88+0,17 \text { GSF }_{t}+0,01 \text { SES }_{t}-1,04 \text { OOP }_{t}+0,11 \text { Trade }_{t}-0,20 \text { Debt }_{t}-1,002 \text { Infl }_{t}
$$

Table 4 confirms the long-run equilibrium relationship between the explanatory variables and economic growth. The coefficient of adjustment towards equilibrium [CointEq(-1)] is statistically significant and negative. In other words, it is a parameter that adjusts the shocks to the economic growth variable. Following a shock, the economic growth response variable returns to equilibrium with a frequency of $0.56 \%$. The shock is fully resolved after two years $(1 / 0.56=1.78)$.

The economic modeling results reveal that external debt is negatively related to economic growth in the short run. The result remains plausible because, in the short run, external debt cannot boost economic activity. When the external debt increases by $1 \%$, the economic growth rate decreases by $1.10 \%$. However, the said modeling indicates that debt on economic growth is statistically negative and small in the long run, reducing the change in real GDP by $0.20 \%$. From this result, it appears that external debt does not create value-added through investment. Moreover, in Morocco, the long-run finding suggests that external debt is directed towards unproductive and rentier sectors, where shortfalls and critical shares are used to wage bills and consumption expenditures.

In the short term, the estimation of our econometric specification shows that inflation has a significant negative impact on economic growth. A $1 \%$ increase in inflation leads to a decrease in the economic growth rate of $0.69 \%$. This low level of inflation rate subsequently leads to a decrease in the sales prices of the companies, and consequently, a decrease in their profit margins. As a result, this inflation control slows down investment incentives, which reduces the level of private investment, thus leading to a decrease in national production. The negative impact of inflation on economic growth becomes high in the long run due to inflation targeting by monetary authorities.

Because low inflation reduces prices and profit margins and causes companies to reduce their investments, as a result, companies are forced to freeze wages, stop hiring, and lay off employees. The effect further punishes indebted companies, especially when the inflation rate is lower than the interest rate. The companies whose income is low have more financial constraints, and therefore it would always be more difficult for them to repay their loans which restrict their investments. This, in turn, affects their economic competitiveness, which leads to a decrease in valueadded, and consequently, a decrease in the rate of economic growth.

From the estimation results of these two economic quantities, we can deduce that the low level of inflation influences companies' competitiveness and the government's budget. In other words, the low level of the inflation rate creates difficulties for the government in terms of repaying external debt, which makes the debt heavy and unfavorable to our economy.

Concerning the control variables, the estimate shows that trade openness has no short-term effect on economic growth. This is because the government's trade policy is a long-term policy. In the short term, public authorities negotiate bilateral relations between countries based on economy, law, and so forth. On the other hand, the degree of openness positively influences economic growth in the long term, although the impact remains low (0.11\%). This impact is explained by the low quality of the Moroccan exportable offer (underperformance of world trades) and the free trade agreements, which do not make any sectoral contribution and do not adjust the trade balance.

The population growth rate variable is negatively and significantly related to the economic growth rate in both the short and long terms. This is a logical result because when the population increases, government spending 
increases to meet the needs of an economy characterized by high population growth. As a result, the pace of economic growth declines as the population increases.

The proxy variables for physical and human capital are statistically positive. These are the crucial factors of national production. Any increase in these factors leads to an increase in economic growth, all things being equal.

\section{CONCLUSION}

The impact of public debt on economic growth is at the heart of the research debate. Public debt represents a source of macroeconomic imbalance, which weakens the real economy. However, if the debt is directed towards productive sectors capable of creating wealth, it becomes a source of external financing and a mechanism for macroeconomic recovery. Thus, inflation plays an essential role in the relationship between debt and economic growth.

The main objective of this work is to assess the effect of inflation and external debt on Moroccan economic growth. Our study covers the period from 1985 to 2019. The descriptive analysis of the main stylized facts shows that the profile of Moroccan economic growth remains weak and depends on volatile sectoral value-added, especially agriculture, regarding external financing and external debt; the latter increases in economic crises or poor fiscal conditions. Concerning monetary policy, the inflation rate is trending around zero, indicating that efforts are being made by the monetary authorities to target inflation.

Using the ARDL model, the results show that external debt has a significant negative impact on economic growth. This finding is explained by the unproductive destination of the debt, which is channeled much more towards consumption. The results also reveal that the low level of inflation slows down economic recovery and thus causes difficulties in debt repayment, and consequently, a decline in economic growth.

Regarding the control variables, trade openness has a positive impact on the rate of change of GDP. However, this impact remains weak in the long term. In contrast to the long-run result, the modeling indicates that the degree of openness does not influence economic growth in the short run. Thus, population growth reduces the level of risk created, which leads the government to increase public spending in a society with a high demographic profile. Finally, the econometric modeling asserts that two factors are vital to boost economic growth, namely physical and human capital. These are statistically positive and significant.

Despite the efforts made by public authorities in terms of economic recovery and the remedy against negative market externalities, some factors distort debt spending. Through the modeling results, our study proposes two main measures to mitigate the effect of these factors. First, there is a need to develop better institutional and governance quality. The latter allows debt funds to be well spent on non-rentier sectors capable of reviving the Moroccan economy. Second, we must seek good inflation, in other words, inflation that stimulates economic activity without creating economic distortions.

Future studies could explore another avenue of research, that of the role of institutional quality. The economic literature suggests that institutional quality constitutes an important transmission channel between debt and economic growth. Thus, another study that may be of interest along these lines of research is the moderating effect of exchange rate devaluation.

Funding: This study received no specific financial support.

Competing Interests: The authors declare that they have no competing interests.

Acknowledgement: Both authors contributed equally to the conception and design of the study.

\section{REFERENCES}

Agénor, P.-R., \& Peter, M. (1996). Development macroeconomics. New Jersey: Princeton University Press. 
Barro, R. J. (1979). On the determination of public debt. Journal of Political Economy, 87(5, Part 1), 940- 971. Available at: https://doi.org/10.1086/260807.

Ben, L. L. (2014). Public debt and economic growth: Empirical investigation for the euro area, the European Union and advanced countries. Economic Nerws, 90(2), 79-103.

Chowdhury, A. (2001). External debt and growth in developing countries: A sensitivity and causal analysis. WIDER-Discussion Papers. World Institute for Development Economics Research Discussion Paper 2001/95.

Clements, B., Bhattacharya, R., \& Nguyen, T. Q. (2003). External debt, public investment, and growth in low-income countries. IMF Working Paper WP/03/249.

Cohen, D. (1993). Low investment and large LDC Debt in the 1980's. The American Economic Review, 83(3), 437-449.

Corden, W. M. (1988). Debt relief and adjustment incentives. Staff Papers, 35(4), 628-643. Available at: https://doi.org/10.2307/3867113.

Diamond, P. (1999). National debt in a neoclassical growth model. American Economic Review, 55(5), 1126-1150.

Ferreira, M. C. (2009). Public debt and economic growth: A Granger causality panel data approach. School of Economics and Management, Technical University of Lisbon. Department of Economics, Working Paper 24/2009.

Guissé, O. (2016). Effects of public debt on economic growth in the presence of non-linearity: The case of the countries of the West African Economic Union and Monetary Union. Ph.D. Thesis Submitted on April 22, 2016 at the University of Orleans, France.

Hwang, J.-T., Chung, C.-P., \& Wang, C.-H. (2010). Debt overhang, financial sector development and economic growth. Hitotsubashi Journal of Economics, 51(1), 13-30.

Jerome, O. (2013). External debt and the quality of institutions: Impact on economic growth: The case of UEMOA. Paper presented at the The Renaissance of African Economies Conference, Dar Es Salam, Tanzania, 20-2 1 / 12/2010.

Karagöl, \& Erdal. (2002). The causality analysis of external debt service and GNP: The case of Turkey. Central Bank Review, 2(1), 39-64.

Krugman, \& Paul. (1988). Financing vs forgiving a debt overhang: Some analytical issues. Working Paper, No 2486. Cambridge, Massachusetts: National Bureau of Economic Research.

Narayan, P. K. (2005). The government revenue and government expenditure nexus: Empirical evidence from nine Asian countries. Journal of Asian Economics, 15(6), 1203-1216. Available at: https://doi.org/10.1016/j.asieco.2004.1 1.007.

Ndoricimpa, A. (2020). Threshold effects of public debt on economic growth in Africa: A new evidence. Journal of Economics and Development, 22(2), 187-207. Available at: https://doi.org/10.1108/jed-01-2020-0001.

Oumansour, N.-E., \& Chkiriba, D. (2019). External public debt and economic growth in Morocco: Assessment and impacts. Global Journal of Management and Business Research, 8(2), 80-95. Available at: https://doi.org/10.20472/es.2019.8.2.006.

Pattillo, C., Hélène, P., \& Luca, R. (2004). What are the channels through which external debt affects growth? IMF Working Paper 04/15. Washington: International Monetary Fund.

Pesaran, M., \& Shin, Y. (1998). An autoregressive distributed-lag modelling approach to cointegration analysis, in Econometrics and Economic Theory in the 20th Century: The Ragnar Frisch Centennial Symposium, (pp. 371-413). New York: Cambridge University Press.

Pesaran, M. H., Shin, Y., \& Smith, R. J. (2001). Bounds testing approaches to the analysis of level relationships. Journal of Applied Econometrics, 16(3), 289-326. Available at: https://doi.org/10.1002/jae.616.

Saint-Paul, G. (1993). Two essays on economic growth. Working Paper, No. 9316, Delta.

Sani, A., Said, R., Ismail, N. W., \& Mazlan, N. S. (2019). Public debt, institutional quality and economic growth in Sub-Saharan Africa. Institutions and Economies, 11(3), 39-64.

Sen, S., Kasibhatla, K. M., \& Stewart, D. B. (2007). Debt overhang and economic growth-the Asian and the Latin American experiences. Economic Systems, 31(1), 3-11. Available at: https://doi.org/10.1016/j.ecosys.2006.12.002.

Serven, \& Luis. (1997). Uncertainty, instability and irreversible investment: Theory, evidence and lessons for Africa. World Bank Policy Research. Working paper No. 1722. Washington: World Bank. 
Were, M. (2001). The impact of external debt on economic growth in Kenya: An empirical assessment. World Institute for Development Economics Research. Discussion Paper No. 2001/116.

Westphal, C., \& Rother, P. (2012). The impact of high government debt on economic growth and its channels: An empirical investigation for the euro area. European Economic Revierw, 56(7), 1392-1405. Available at: https://doi.org/10.1016/j.euroecorev.2012.06.007.

Woodford, M. (1990). Public debt as private liquidity. American Economic Review, 80(2), 382-388.

Views and opinions expressed in this article are the views and opinions of the author(s), Asian Economic and Financial Review shall not be responsible or answerable for any loss, damage or liability etc. caused in relation to/arising out of the use of the content. 